\title{
Újra a bagoly-ról
}

1. A Magyar Nyelv 113. évfolyamának 3. számában jelent meg egy rövid írásom az addig ismeretlen eredetünek tartott (1. TESz. 1: 217; EWUng. 1: 68) bagoly szóról (NÉMETH 2017). Elsősorban a bogár szó etimológiai lehetőségének párhuzamát láttam meg a bagoly hátterében. A felvetésem egy kérdésben összefoglalva: ha a bogár hangutánzó eredetü és a búg igével függhet össze, akkor lehet-e a bagoly töve is ez az ige (vagy ennek diakrón láncba illeszthető valamilyen változata)?

Alapvetően nem volt más célom, mint egy etimológiai ötlet bemutatása. Az etimológiai kutatások ugyanis a szófejtés bizonyításának különböző fokán eltérő „műfajt” képviselnek, legalsóbb szinten az etimológiai ötlet helyezkedik el (1. SZENTGYÖRGYI 2010: 43-46). Fontosnak láttam ötletemet abban a formában közreadni, hiszen egy egyszerü ötlet is jobb az ismerethiánynál, illetve az akörül kialakuló lehetséges párbeszéd szintén jótékony hatással van a tudomány haladására.

Erre a felvetésre reagált előadásban (2019. április 30-án az MTA Nyelvtudományi Intézetében) és írt tanulmányt HORVÁTH LÁSZLÓ, amelyben a felvetett etimológia helyett (mert jobb eredetmagyarázattal ő sem tud szolgálni) a szófejtés egyes részeinek kifogásolásával és általánosabb szemléleti-módszertani okból való kritikájával foglalkozik. Bizonyos esetekben az ellenvetések jogosságát magam is elismerem, ugyanakkor módszertani oldalról nem látom okát. Nyilvánvaló, hogy a megfelelő adatok, az azokból levont következtetések és a szakirodalom ismerete mellett az etimológiában nagy szerepe van a tudós alkatának (RÓNA-TAS 2017: 43). Én magam nem módszertani hiányosságként fogom fel, hogy bizonyos kérdésekre nem tértem ki ötletemben.

A módszer hagyományos (BÁRCZI 1958/2001: 8-11): a számomra releváns adatokat elláttam - véleményem szerint szintén releváns - hangtörténeti és szemantikai magyarázattal, kitérve a névadás alapjára is. A szavak eredetének megítélése gyakran változhat (HoNTI 2012: 52), az etimológia tudománya alapvetően ebben különbözik a nyelvtudomány más ágától. Ez szerintem így van rendjén, különösen történeti tudományok esetében. Ha mindenki azonos mennyiségü ismerettel rendelkezne, akkor nem lenne szükség az etimológiák bírálatára és a mögöttük álló érvelés vizsgálatára. Az ismeretek közti különbség a nyelvtudomány rendkívüli széttagoltsága (KISS 2005/2014: 86) mellett abból is adódik, hogy a kutatók eltérő mennyiségű adatot ismernek, illetve az adatokat máshogy vallatják. Így a HoRVÁTH által elszalasztott lehetőségekként elkönyvelt hiányosságok meglátásom szerint a tudós ítélet különbségéből adódnak.

Válaszomban az ötletnél nem tudom magasabb bizonyítási szintre emelni korábbi felvetésemet, de remélem, hogy tisztázni tudok néhány kérdést. Fontos megemlíteni, hogy ismeretlen eredetű szó etimológiáját céloztam meg, a felhozott párhuzamok és a vizsgálatba esetlegesen bevonható elemek csak ötlet szintjén szerepelnek, releváns voltukat csak további vizsgálatok erősíthetik meg.

2. Az etimológiai szótárak adatain alapuló ötletben megvizsgáltam a bagoly történeti előfordulásait. Az 1389-es Bogul adat olvasatának kapcsán hoztam szóba az ómagyar kori 
magánhangzók jelölésében megfigyelhető eltolódást, amelyet BENKŐ vetett fel (BENKÖ 1980: 89-93). Ez a lehetőség a bogul szóalakot is bagol vagy bagoly olvasattal láthatja el.

A bög igéböl képzett bögöly szót is párhuzamba állítottam a bagoly szóval. A némiképp közelebbi példa után nem tartottam szükségesnek a sirály analógiájára való kitérést, egy másik munkában akartam foglalkozni e szó körüli kérdésekkel, remélhetőleg hamarosan lehetőségem lesz rá.

A történeti-etimológiai szótár szerint -ly áll a bagoly végén (TESz. 1: 217), de diakrón szempontból éppen $-l$ is lehet, hiszen ebből palatalizálódhatott. HoRVÁTH LÁSZLÓval abban egyetértünk, hogy a korai írott formák nem nyújtanak kellő támpontot a kiolvasáshoz az azonos jelölés miatt. Ezért említettem meg, hogy a TESz. (talán az ismeretlen eredet miatt) -ly-re korlátozza a szóvég olvasatát a bagoly esetében, holott a bögöly-nél az $-l \sim-l y$ lehetőségét megengedi. Ezért végső soron nem láttam szükségszerüen fontosnak, hogy kitérjek a szóvégi hang palatalizáltságának kérdésére.

3. A bogár szóval kapcsolatban is kitér HORVÁTH LÁSZLÓ bizonyos részletekre. BALÁZS JÁNOS korábbi tanulmányának és MOKÁNY SÁNDOR ezt az ötletet kiegészítő munkájának említését hiányolja. Majd hozzáfüzi, hogy az EWUng. a megfogalmazásom ellenében éppen BALÁzS etimológiája miatt a TESz.-től eltérően már nem tekinti ismeretlen eredetünek, hanem belső keletkezésűnek, valószínűleg a búg ige származékának.

Valóban félrevezetett az EWUng. (BALÁzS ötletének meggyőző volta ellenére) óvatos megfogalmazása. Számomra egyértelmű volt, hogy BALÁZS szófejtésének legújabb változatát említsem meg. Végül a legutolsó ezzel foglalkozó mü, az EWUng. szócikkére hivatkoztam, emiatt hagytam el MoKÁNY ehhez képest korábbi munkáját. Az EWUng. szakirodalmi részéből egyébként sem derül ki, hogy éppen BALÁZS munkája miatt kapott más besorolást a bogár, hivatkozás BALÁZSnak csak az első tanulmányára és MOKÁNYra található - bár ez nyilván a szótárírói elvekkel függ össze. Nem volt szándékom bizonyos adatok elhallgatása.

HORPÁCSI említett cikkét nem ismertem, köszönöm, hogy HoRVÁTH erre felhívta figyelmem. KISS JENŐ könyvét azért hagytam ki, mert nem lép túl a TESz. minősítésén. A filológiai alaposság persze megkívánja mindegyik felvételét, ugyanakkor nem gondolom, hogy hibát követtem volna el akkor, amikor a végső forrásra hivatkoztam.

Mivel a bogár szó etimológiájához semmi újat nem tudok hozzáfüzni, ezért azzal nem is foglalkoztam behatóbban annál, minthogy magát az alapötletet bővítettem ki. Így egyértelmü, hogy az ÚESz.-ben semmi alapja nincs az ötletem e szócikknél való említésének.

4. HORVÁTH számára nem kézenfekvő a búg : bogár : bagoly sorra a mukkan : mókus : makog analógia. Szerinte az elnevezés mögött álló hangadás különbsége miatt váltakozhat az azt tükröztető szavak hangalakja, és lényegében külön muk-, mók-, makigetöveket feltételez. Ezzel voltaképpen felülírja e szócsoport etimológiáját. A történeti kutatásban nagyobb erőt tulajdonít a szinkrónián alapuló egyéni hangérzékelésének és jellemzően a köznyelvi jelentéseket rögzítő ÉKsz. ${ }^{2}$-nek. A váltakozás szerinte tehát csak látszólagos és alapjában az érzékelt hang minőségétől függ.

Ez nemcsak a felvetett ellenvetésben jelent nehézséget, hanem az etimológiai magyarázatban is gyenge lábon áll. Sőt ez valódi módszertani kérdés, hiszen a szinkrón és diakrón viszonyok szerencsétlenül keverednek a történeti magyarázatban. Ugyanis a muk- 
kan, mókus és makog szavak töve azonos (TESz. 2: 825, 945, 972-973; EWUng. 2: 927, 989, 1002). Régi adataik között találunk olyan származékokat, amelyek világosan mutatják, hogy a hangérzékelés történeti korokban eltérő, de még inkább azt, hogy egy alapige különböző nyelvváltozatok történeti fejlödése során szétvált alakjai. A makog adataira lásd: 1673: mokok, mokog, 1702: mokogásáról (1. később újra), 1755: makogott, 1790: makkan. A mókus adatai: 1702: „Az evet méltán neveztetik mókusnak az o̊ mokogásáról”, 1764: Mókos, 1818: Mukuts, 1834: Mukutz; az ÚMTsz. adataiból: makkus, mokus, mukus, mukis. Végül a mukkan-ra: 1784: makkanni és ÚMTsz. mokkan.

Az alapige a nyelv térbeli és időbeli változásának eredményeként válhatott szét több alakra az egyes belső változatokra jellemző egyéni folyamatokban a szóképzés és lexikalizáció során, amelyek között az összefüggés olykor el is vesztette átláthatóságát. Így a szinkróniában egymás mellé kerülő három különböző nyelvállásfokot képviselö alak a történetiségben világosan összetartozik, de többnyire nem váltakozik, mert a különbözö belső változatokban eltérő nyelvállásfokon áll.

De a fenti példán kívül is találunk más onomatopoetikus igén alapuló állatnevet, amely szintén ilyen megoszlást mutat. Ez az adat mind a diakróniában, mind a szinkróniában megőrizte az összetartozást: dungó dongó dangó. Ennek van dangócs változata is; igaz, csak a dangó és bagócs izoglosszái mentén (IMRE 1987: 30-31). Ez a hármas megoszlás már tekinthető váltakozásnak, de csak a szótárban és a nyelvatlasz lapjain, vagy a nyelvjárási alakváltozat és a köznyelvi megfelelő egyidejü használatában. Ezért szerencsésebb a szinonima helyett tautonima névvel illetni ezt a viszonyt (IMRE 1987: 10). Diakrón szempontból BENKŐ szóhasadás-felfogásába (több szinten is) beilleszthető ez a különbségtétel (BENKÖ 1963/2003: 347). Ez a viszony illik GOMBOCZ által megadott hangutánzó-hangfestő igék több jellemzőjére (GOMBOCZ 1913: 387-391). Így könnyen érthető, hogy a történetileg összekapcsolódó igetövek a köznyelvben nem feltétlenül mutatják felismerhetően az összetartozást.

5. HoRVÁth LÁszló érveléséből ezt mindenképpen kiemelném: „A jelentéstani, onomasziológiai elemek nagyrészt (noha nem teljesen) támogatják az eredetmagyarázatot. A feltételezett morfológiai mozzanat, a képzésmód szintén. Súlyos nehézséget jelent viszont az, hogy mind a bagoly szónak a bugoly változata, mind pedig a búg igének a bag variánsa vagy az önállónak tekinthető bag ige hiányzik.” A súlyosság megítélése lehet szubjektív, de amíg a részletek tisztázatlanok maradnak, addig valóban bizonytalan az etimológia.

Ez a kijelentés legfeljebb a bugoly hiánya miatt lehet elgondolkodtató, de kizáró ok nem lehet, hiszen a búg igének bog változatára éppen HORVÁTH utalt. Így a bugoly keresése, ha már a bog megvan, kevésbé lehet indokolt. Noha fontos szempont, hiszen a hozott analógiák tagjaiban kimutatható: dungó, mukkan. Valószínủleg egyébként hasonló analógiás hatások hozták létre ezeket a többirányú változásokat: az egyikben a középső nyelvállású alapige a központi elem: dong (vö. döng), a másikban az alsó makog és felső mukkan ma tipikusabb, de régen a mokog talán alapvetőbb lehetett. Ennek tükrében továbbra sem látom akadályát a dongó $>$ dangó, R. mokog $>$ makog mintájára a bogoly $>$ bagoly változás lehetőségének. Sőt a dongó esetében egy dongó > dungó változás is szóba jöhet, ami pedig a bogoly esetében nem feltétlenül következett be, ezért nincs *bugoly adatunk.

Ha a hangutánzástól eltávolodunk, egy hangfestő csoport példája is azt mutatja, lehetséges a nyílt és a zárt forma együttélése; erre részletesebben a 7. pontban fogok kitérni. 
Egyelöre csak a releváns régies és nyelvjárási alakokat említem, amelyek itt is láncot alkotnak: bukdácsol : bokdácsol : bakdácsol (ejtve: bugdácsol : bogdácsol : bagdácsolegyes forrásközlésekben az alakváltozatok között felbukkan a $g$-s, zöngésségi hasonulást tükröző írásmód is, pl. bogdácsol.)

6. A búg igéből való kiindulást nem tekintettem egyedüli lehetséges magyarázatnak. HORVÁTH LÁSZLÓ megfogalmazása ebben az esetben szerintem túl erős, szerencsésebb lett volna itt is megemlíteni a másik felvetésemet, nem csak a későbbiekben, mert azt sugallja, hogy az $u>o>a$ változást tartom eredetibbnek. Ezáltal úgy tünik, mintha nem ehhez tartozóan, hanem csak a bögöly párhuzamaként vettem volna fel a kétszeres nyíltabbá válás mellett az általam csak feltételezett *bog, *bóg igét is.

Amit tényleg ellenőriznem kellett volna, az a bóg, bog ige jelenléte a régiségben. Köszönöm, hogy e hiányosságra rámutatott HoRVÁTH. Ha ezt megtettem volna, nemcsak rekonstrukcióként vettem volna fel a bog igét, hanem mint az EWUng. is mutatja, létező elemként, bong alakváltozattal (vö. dung dúg, EWUng. 1: 273). Én ellenben emiatt nem a hiányosságra koncentrálok, hanem a következtetés helyességére.

Így tehát a középső nyelvállásfokú bogoly lehetőségét rejti a cikkem, ilyen alakot egyébként közlök is: bogoly (ÚMTsz. 1: 304). Sőt korábban a BENKÖ felvetésén alapuló másik lehetőséggel bemutatott bogul alak akár így is kiolvasható. De bugoly változat valóban nem bukkan fel.

A palatális : veláris párok esetében bizonytalanságomat és a kétféle magyarázat lehetőségét fenntartó gondolatmenetem interpretálásában HORVÁTH megint egyoldalúan jár el. „Bár a hangalak motiváltsága önmagában is okozhat szabálytalanabb viselkedést, de számolhatunk rendszerszerü fejlődésekkel is. [...] A különlegesebb viselkedésre utalhat, hogy palatoveláris párhuzamok is kialakulhattak: dong $\sim$ döng, gyúr $\sim$ gyür stb. - tehát hangutánzó alakpárok azonos nyelvállásfokon is létrejöhetnek.” - így fogalmaztam, ha kihagyjuk a hangváltozással foglalkozó részt. Ezzel kapcsolatban ezt írja HORVÁTH: „A bagoly : bögöly kettőst NÉMETH palatoveláris hangutánzó párokra utalva hozza szóba. Példái közül azonban csak a dong döng megfelelö, mivel a gyúr $\sim$ gyür nem onomatopoetikus (TESz., EWUng.)".

Elismerem, talán a megfogalmazásom tényleg nem a legszerencsésebb. De látszik, hogy eleve kétféle lehetőséggel számolok. A hangrendi kérdések kapcsán a vesszővel ellátott sor első tagja vonatkozik az onomatopoetikus háttérre, a második tag a rendszerszerü fejlődésre, amennyiben pl. az intenzitás kifejezése annak tekinthető. Bár ha már szóba jött a második páros, az azért gyanús, hogy az EWUng. magyarázatában (1: 502) a gyür ismeretlen eredetü, de összefüggését a gyúr-ral olyan oldalról tartja elfogadhatónak, mint ahogy a hangutánzó csattan : csetten, szortyogtat : szörtyögtet összefügg. Ez így pedig a gyúr ige ótörök eredeztetése (1: 501) szempontjából vethet fel kérdéseket, hiszen a felhozott párhuzamok hangutánzó eredetủek. Ebből a szempontból azonban valószínüleg a hangfestő jelleget kellene vizsgálni.

7. A búgás és huhogás kapcsán a véleményünk nem tér el jelentősen. Én is arra gondoltam, hogy a hangadás megnevezése változott, vagyis az azt tükröztető hangsor más hangokkal történt. A madarak hangképzésének folyamatossága a búgás és szakaszossága a huhogás esetén sem döntő érv a két hangadás szétválasztására. Hangtörténeti érvek ki- 
zárják, hogy a búg és huhog ige régiségben is az legyen, de ma szerintem is szinonima a madarak hangadásának leírására. A búg esetében azonban jelentésszükülés miatt a beszélök felfogásában a baglyok kikerülhettek a lehetséges madarak közül, a huhog esetében a $h$ (és a szóvégi képző) jelenléte miatt biztosan későbbi. Az ómagyar korra mindkettő jelenléte feltehető, de a búg talán némileg korábbi is lehet. Megfogalmazásom részben erre is utal; HoRVÁTH szerint a régiségben is szinonimák lehettek, amivel maradéktalanul nem értek egyet.

Az etimológiai szótárak másrészről felvetik annak a lehetőségét, hogy a búg alapszava egy bú indulatszó is lehet (TESz. 1: 378-379; EWUng. 1: 142), ebben az esetben valóban képző jelenlétével van dolgunk. Sőt ezzel párhuzamos lehet a búgat alak a -gat képzőbokrával, hiszen ez azt jelenti, hogy a két származék egyaránt a bú-ból való.

Itt már felvetődhetnek olyan morfológiai kérdések, hogy hogyan viszonyul egymáshoz a búg, buhog (NMTsz. 104) és a huhog. Hiszen egy buhog alak végén jobban érzékelhető a gyakorító képző, mint a búg-én. Annak az eldöntése, hogy így egy buhog : búg összefüggés elképzelhetö-e, és hogy egy suhog : súg, zuhog : zúg és vihog : víg (e szó a TESz.-ben ismeretlen eredetü, 1. 3: 1140-1141; az EWUng.-ban bizonytalan, 1. 2: 1633) sorhoz hasonló analógia felállítható-e, további vizsgálatokat igényel.

További nehézséget jelent, hogy a buhog kapcsán ilyen nyelvjárási szavakat is találunk: buha1 'bagoly', buha ' 'borzas, kócos', buhagos 'sürü, tömött', buhu 'bagoly' és 'buksi, fej', valamint buhú 'nagy fülesbagoly', illetve talán még a buhint 'köhint' is ide sorolható (vö. NMTsz. 105). Ez látszólag ellene szól az általam felvetett etimológiának, és éppen a CzF. másik - amúgy gyengébbnek tünő - magyarázatát erősítené (CzF. 1: 378), mely a névadás alapjául a madár busa, nagy fejét adja meg, így a bog névszóval kapcsolja össze. Ez inkább fordítva történhetett. Előbb lehetett a hangutánzó szó, amelyből a bagolyra alkalmazott név, majd abból a 'kócos' és 'tömött', végül az ilyen fej megnevezéséül szolgáló szó.

8. Szintén köszönöm HoRVÁTHnak, hogy kitért a bagócs 'bögöly’ példájára. Az adatot ismertem, de csak a bögöly nyelvjárási változataként, önálló szóként nem. A TESz.féle magyarázat közül az elsőt támogatom is, az EWUng. magyarázatát én sem látom meggyőzőbbnek. A mondanivaló szükítésekor emiatt az ellentmondás miatt is maradt ki: bővebb magyarázattal való ellátást igényelt volna bevonása, nem kívántam egy fél mondattal megemlíteni. Utólag lehet, hogy szerencsésebb lett volna.

Előadásában tovább is ment HORVÁTH, kifejezte értetlenségét azt illetően, hogy ha lenne *bag- ige, akkor mi lenne a végén az -ócs. Véleményem szerint a bogócs $>$ bagócs esetében a (népetimológiás?) *bagó 'búgó' folyamatos melléknévi igenévhez kapcsolódhatott a -cs kicsinyítő képző. A bagoly szónak bagó alakja pedig talán a szóvégi mássalhangzó elmaradásából adódó nyúlás eredménye, nem pedig a bagócs alapszava.

Végül abban is egyetértünk, hogy a bagzik esetében a korábbi megfogalmazás kérdéses. Valóban adja magát a $-z$ denominális képző felőli magyarázat, de továbbgondolva a *bag-ige esetében nem zárható ki, hogy a szóvégi -g-t a nyelvérzék gyakorító igeképzőként fogta fel és a szót igeként értelmezte. Feltételezésem szerint a bakzik esetében szóba jöhet a bak fónévből való származtatás mellett a nyelvjárási bag- mint 'búg' igével való népetimológiás beleértés vagy vegyülés lehetősége is. Ha létezhetett a *bag-ige, akkor a bog-nak nyelvjárási változata lehetett a régiségben is. De talán szerencséseb a bog-igéből való származékok kialakulása után feltenni (talán csak az etimológia transzparensségének elvesztése után) a nyíltabbá válást. 
Még ki kell térni a bagzik bakzik ige esetében néhány morfológiai kérdésre. HoRVÁTH azt mondta, hogy ezeknek alapszava a bak fönév lehet, a g-s változat zöngésség szerinti hasonulás eredménye. Csakhogy a régi és nyelvjárási alakok vizsgálatánál a magyarázatnak itt is tovább kell mennie, hiszen néhány részlet nála is tisztázatlan marad.

Igék esetében is, képző után találunk efféle a végződést, pl. fárad : fáradozik. Így tehát az a kifogás sem olyan egyértelmü, hogy mit keresne a bagzik-ban a $z$ elem. Hiszen ha valóban érezhető a - $g$ képzőnek (l. fent bú : búg), amely népetimológiás beleértését a *bag- igei tő elhomályosulása is okozhatta, akkor a $-z$ jelenléte is indokoltabbá válik. Így a bagozik alakok (bak : bagzik : bagozik) sem feltétlenül névszói tövüek. Lásd még a bagoz, bakozik, baklat, baklatik alakot is (NMTsz. 48, 50). E két l-t mutató változat esetében talán a zaklat ige és családjának 'zörej, lárma' és 'izeg-mozog' meg 'izgága személy' jelentésű származékok besugárzásának vizsgálatát is fontosnak tartom (a TESz. még ismeretlen eredetünek tartja a zaklat igét, de a zakatol igét hangutánzónak, 3: 1184-1185; az EWUng. már összeköti a szócsaládot, 2: 1658-1659). Ha más oldalról nem is, népetimológiás alapon, hiszen így a baklat esetében is a zaklat-féle hangadást és mozgást tekinthették a névadás alapjának.

Emellett talán érdemes lenne azt is megvizsgálni a bak névszón kívül, hogy milyen viszonyban van a bagzik és bakzik a részben régies, hangfestó és nyelvjárási szinten terebélyes szócsaláddal: baksál, baktat, bagadozik, bakadoz, valamint bukik, bukdácsol : bogdácsol : bakdácsol (vö. TESz 1: 224-225; EWUng. 1: 72; a Nszt. még a bagdácsol alakot is közli, 4: 345-346).

Én mindenképpen távolabb tartanám egymástól a kiejtés és íráskép (másodlagos) viszonyát ebben a kérdésben. HORVÁTH véleményével szemben nem gondolnám, hogy a bagzik esetében a búg, bőg szavak írásmódja lenne döntő a bakzik alakkal szemben. Talán inkább a tájnyelvi alak igen korai köznyelvi szintre emelkedése vagy a szóalakok vegyülése ( $b o g$ ige nyelvjárási bag változata és a bak állatnév vegyülése) vagy a népetimológia erösebb, végső soron a hagyomány elve jöhetne szóba.

Ez utóbbi viszont felvet további kérdéseket. Mert kisebb kronológiai bonyodalom van a származékok és a tőszó körül. Az EWUng.-ban a bak első biztos szn.-i előfordulása 1211-ből, köznévi 1329-ből való, a TESz.-ben 1395 körülröl. Ezzel szemben a bagziknak 1283-ból van a Bokzou szn. adata, köznévi 1519-ből, a TESz.-ben $k$-s alak 1604-böl van. Ennek megemlítése egyáltalán nem lényegtelen, még akkor sem, ha természetesen az adatok a véletlennek kitéve maradtak fenn, ugyanis ez magyarázatot igényel és gyengíti az érvelést. Főleg, hogy a korai ómagyarban még mindkét irányú hasonulás is lehetséges volt (E. ABAFFY 2003: 311-312), és éppen bakzik alakot kellene várnunk köznyelvi szinten is. Ezen etimológia szerint a bagzik ige bak $+-z(i k)$ elemsorának kiejtése [bakszik] is lehetett, és ezzel egy másik sorba, az -sz képzősök közé is illeszkedhetne a korabeli beszélők tudatában (vö. fekszik, alszik stb.).

9. Ismeretlen eredetü szavak etimológiájának megfejtése az egyik legizgalmasabb, de egyúttal a legnagyobb kihívással járó feladat. E szavak jelentős része lehet hangutánzó, hangfestő hátterű, e szócsoport vizsgálata belső problémáik miatt különféle módszert igényel. Amit tehetünk, az az ötletek óvatos felvetése a távolabbi kapcsolatok felvázolásával. De az ötlet mindig jobb az ismerethiánynál.

Ugyanakkor az is egyértelmü, hogy egy erős etimológia a minden részletre kiterjedő magyarázat. A bagoly megfejtésére irányuló ötletem nem volt ilyen. Bár szerintem nem 
feltétlenül szükséges és nem is mindig lehetséges, hogy egy kutató egyszerre feleljen minden kérdésre.

Remélem, válaszom után ismét csökkent a bagoly körüli ismeretlenek száma. Ha bizonyos kérdések egyértelmủ megválaszolására a párbeszéd kialakulása után sincs lehetőség, akkor újabb adatok felkutatására, illetve távolabbi kapcsolatok és összefüggések felismerésére kell törekedni. Bízom benne, hogy a bagoly körül kialakult közös gondolkodás a tudomány hasznára válik - sőt kívánatosabb is volna több vita a tudományos életben.

\section{Hivatkozott irodalom}

E. ABAfFy ERZSÉBET 2003. Hangtörténet [Ómagyar kor]. In: KISS JENÖ - PUSZTAI FERENC szerk., Magyar nyelvtörténet. Osiris Kiadó, Budapest. 301-351.

BÁRCZI GÉZA 1958/2001. A magyar szókincs eredete. Tinta Könyvkiadó, Budapest.

BENKŐ LORÁND 1963/2003. Adalékok az ősmagyar szóhasadás eseteihez. In: HAJDÚ MiHÁLY KISS JENÖ szerk., Nyelv és tudomány - anyanyelv és nyelvtudomány. Válogatás Benkö Loránd munkáiból 1. ELTE BTK Magyar Nyelvtörténeti, Szociolingvisztikai, Dialektológiai Tanszék, Budapest. 346-374.

BENKÖ LORÁND 1980. Az Árpád-kor magyar nyelvü szövegemlékei. Akadémiai Kiadó, Budapest.

CzF. = CZUCZOR GergelY - FogARAsi JÁNOS, A magyar nyelv szótára 1-6. Emich / Athenaeum, Pest / Budapest, 1862-1874.

ÉKsz. ${ }^{2}=$ Magyar értelmezö kéziszótár. Főszerk. PuszTAI FERENC. 2., átdolgozott kiadás. Akadémiai Kiadó, Budapest, 2003.

EWUng. = Etymologisches Wörterbuch des Ungarischen 1-2. Hrsg. BENKÖ, LORÁND. Akadémiai Kiadó, Budapest, 1993-1995.

GoMBOCZ ZolTÁN 1913. Hangutánzás és nyelvtörténet. Magyar Nyelv 9: 385-391.

HoNTI LÁszLó 2012. Hangtani és szemantikai megfelelés az uralisztikai etimológiai kutatásban. Nyelvtudományi Közlemények 108: 43-60.

HoRvÁth LÁszló 2019. A bagoly eredetmagyarázatához. Magyar Nyelv 115: 205-211. https://doi. org/10.18349/MagyarNyelv.2019.2.205

IMRE SAMU 1987. Nyelvjárási szókészletünk néhány szerkezeti kérdése a magyar nyelvatlasz alapján. Akadémiai Kiadó, Budapest.

KISS JENŐ 2005/2014. Etimológia és nyelvtudomány. In: JUHÁSz DEZső szerk., Kérdések és válaszok a nyelvtudományban. Jelen, múlt, jövő. Válogatás Kiss Jenö tanulmányaiból 2. ELTE Eötvös Kiadó, Budapest. 85-88.

NMTsz. = Nagy magyar tájszótár. Főszerk. KISS GÁBOR. Tinta Könyvkiadó, Budapest, 2019.

NÉMETH DÁNIEL 2017. A bagoly és társai. Magyar Nyelv 113: 356-357. https://doi.org/10.18349/ MagyarNyelv.2017.3.356

Nszt. = A magyar nyelv nagyszótára 1-[7]. Főszerk. ITTZÉS NóRA. MTA Nyelvtudományi Intézet, Budapest, 2006-[2018].

RÓNA-TAS ANDRÁS 2017. Vitás magyar etimológiák. Válasz Honti Lászlónak. Nyelvtudományi Közlemények 113: 37-84. https://doi.org/10.15776/NyK.2017.113.2

SZENTGYÖRGYI RUDOLF 2010. A tihanyi apátság alapitólevele mint a magyar nyelvtörténeti kutatások forrása. ELTE BTK, Budapest. [Doktori disszertáció.]

TESz. = A magyar nyelv történeti-etimológiai szótára 1-3. Főszerk. BENKÖ LORÁND. Akadémiai Kiadó, Budapest, 1967-1976.

ÚMTsz. = Új magyar tájszótár 1-5. Főszerk. B. LÖRINCZY ÉVA. Akadémiai Kiadó, Budapest, 19792010. 